\title{
Analisis Kondisi Psikologis Siswa Dan Implikasinya Terhadap Program Bimbingan Dan Konseling
}

\author{
Hayu Stevani ${ }^{* 1}$, Riska Andriani ${ }^{2}$, Fijriani Fjriani ${ }^{3}$ \\ ${ }^{123}$ Program Studi Bimbingan dan Konseling, Universitas Indraprasta PGRI \\ 1hayu.stevani@gmail.com, ${ }^{2}$ riskaandriani366@gmail.com ${ }^{3}$ opietalone@gmail.com.
}

$\begin{array}{ccc}\text { First received: } & \text { Revised: } & \text { Final Accepted: } \\ \text { 01 October } 2019 & \text { 02 November 2019 } & \text { 04 December 2019 }\end{array}$

\begin{abstract}
Psychological conditions are things that can not be seen directly by the five senses. For example sleeplessness, there are feelings of guilt, thinking no life-threatening, it can not respond to others when asked, and many other psychological problems. In guidance and counseling, AUM umum helps to unravel the psychological conditions through nine field problems. The population and sample of the study included 91 students of class VII and VIII SMP IT Tariq ibn Ziyad Boarding School using AUM umum F-3 for data collection. Results of research for class VII revealed the problem area in PDP, HSO, and JDK, and for class VIII is the problem area in PDP, and HSO got the highest yield of nine-field problems. Based on the interpretation of general AUM results, a description of the student's psychological condition can be an input for the school counselor to create the program and perform the service, most specifically to the field of issue that gets special attention.
\end{abstract}

Keywords: AUM Umum, Guidance and Counseling Program, Psychological Conditions.

\begin{abstract}
Abstrak
Kondisi psikologis adalah hal-hal yang tidak bisa dilihat langsung oleh panca indera. Misalnya sulit tidur, ada perasaan bersalah, berpikir tidak mengancam jiwa, tidak bisa menanggapi orang lain ketika ditanya, dan banyak masalah psikologis lainnya. Dalam bimbingan dan konseling, AUM umum membantu mengungkap kondisi psikologis melalui sembilan masalah lapangan. Populasi dan sampel penelitian ini termasuk 91 siswa kelas VII dan VIII SMP IT Tariq ibn Ziyad Boarding School menggunakan AUM umum F-3 untuk pengumpulan data. Hasil penelitian untuk kelas VII mengungkapkan area masalah di PDP, HSO, dan JDK, dan untuk kelas VIII adalah area masalah di PDP, dan HSO mendapat hasil tertinggi dari sembilan masalah lapangan. Berdasarkan interpretasi hasil AUM umum, deskripsi kondisi psikologis siswa dapat menjadi masukan bagi konselor sekolah untuk membuat program dan melakukan layanan, paling khusus untuk bidang masalah yang mendapat perhatian khusus.

Kata Kunci: AUM Umum, Program BK, Kondisi Psikologis.
\end{abstract}

\section{PENDAHULUAN}

Pendidikan merupakan upaya untuk membantu perkembangan peserta didik sebagai makhluk individu dan makhluk sosial, sehingga dapat hidup secara efektif (Barseli \& Ifdil, 2017; Iceu, 2011). Melalui pendidikan, peserta didik dibekali dengan berbagai ilmu pengetahuan, mengembangkan nilai-nilai moral dan keterampilannya. Dengan demikian sekolah menjadi tempat terjadinya proses pembelajaran yang dapat membekali peserta didik menjadikan mandiri dalam bertindak dan mengambil keputusan (Afandi, 2011).

Namun, tidak dapat dipungkiri bahwa pada proses pembelajaran peserta didik dapat mengalami berbagai permasalahan (Imran, 2013) seperti masalah sosial ataupun masalah pribadi, pada tahun 2016 terungkap bahwa remaja mengalami 
masalah tentang hubungan dengan teman sebaya sebanyak $54,81 \%$, dan masalah emosional sebanyak 42,2\% (Emosi et al., 2010). Selain itu, pada tahun 2015 tercatat sebanyak $65 \%$ remaja memiliki masalah di keluarga mereka seperti masalah keuangan, masalah percerain orang tua, dan lainnya (Puslitbang, Sosial, \& Timur, 2015). Permasalahan tersebut merupakan gambaran psikologis yang tidak dapat dihindari, akan tetapi dapat dikurangi dengan melakukan tindakan preventif dari sekolah terutama oleh bimbingan dan konseling.

Bimbingan dan konseling mampu mengungkapkan berbagai jenis permasalahan peserta didik dengan membagi menjadi masalah umum dan masalah belajar (Prayitno 1997; Imran, 2013; Ifdil \& Ilyas, 2017). Untuk menggambarkan kondisi psikologis peserta didik secara umum maka yang digunakan adalah Alat Ungkap Masalah (AUM) umum (Nurhasanah \& Farozin, 2019). Adapun bidang masalah AUM umum diantaranya Jasmani dan kesehatan (JDK), Diri pribadi (DPI), Hubungan sosial (HSO), Ekonomi dan keuangan (EDK), Karir dan pekerjaaan (KDP), Pendidikan dan Pelajaran (PDP), Agama, Nilai dan Moral (ANM), Hubungan Muda Mudi dan Perkawinan (HMP), Keadaan dan hubungan dalam Keluarga (KHK), Waktu senggang (WSG)
(Prayitno, 2012). Berbagai bidang masalah tersebut akan mengungkapkan gambaran psikologis peserta didik yang akan ditindak lanjuti oleh konselor sekolah dalam pembuatan program bimbingan dan konseling dan pemberian layanan.

\section{METODE}

Penelitian ini tergolong pada penelitian deskriptif, yang mendeskripsikan secara sistematis faktual dan akurat sehubungan dengan fakta-fakta, situasisituasi atau kejadian-kejadian yang ada di lapangan (Arikunto, 2006), hal tersebut berkenaan dengan fenomena kegiatan bimbingan dan konseling di sekolah. Subjek penelitian ini mencakup seluruh siswa kelas VII dan VIII SMP IT Thariq bin Ziyad Boarding School pada tahun ajaran 2016-2017 sebanyak 91 orang. Pengumpulan data dalam penelitian ini dilakukan dengan mengumpulkan data yang diperoleh melalui penyebaran AUM Umum.

\section{HASIL TEMUAN}

\section{Masalah pada siswa kelas VII}

Hasil dari pengisian AUM umum oleh siswa kelas VII akan diuraikan dalam data kelompok, yang terdiri dari tiga kelas (A, B, dan C). masalah pada bidang PDP, JDK, dan HSO. Berikut tabel hasil data kelompok kelas VII:

ANALISIS DATA KELOMPOK AUM UMUM KELAS VI

\begin{tabular}{|c|c|c|c|c|c|}
\hline \multirow{2}{*}{$\begin{array}{c}\text { Bidang } \\
\text { Masalah }\end{array}$} & \multicolumn{3}{|c|}{ Masalah Keseluruhan } & \multicolumn{2}{c|}{ Masalah Berat } \\
\cline { 2 - 6 } & Jumlah & $\%$ & $\begin{array}{c}\text { Rata-rata } \\
\text { persiswa }\end{array}$ & Jumlah & $\begin{array}{c}\text { Rata-rata } \\
\text { persiswa }\end{array}$ \\
\hline JDK (25) & 258 & 19,8 & 5,0 & 32 & 0,6 \\
\hline DPI (20) & 224 & 17,2 & 4,3 & 20 & 0,4 \\
\hline HSO (15) & 293 & 22,5 & 5,6 & 23 & 0,4 \\
\hline EDK (15) & 68 & 5,2 & 1,3 & 4 & 0,1 \\
\hline KDP (15) & 81 & 6,2 & 1,6 & 5 & 0,1 \\
\hline
\end{tabular}




\begin{tabular}{|c|c|c|c|c|c|} 
PDP (55) & 681 & 52,4 & 13,1 & 42 & 0,8 \\
\hline ANM (15) & 213 & 16,4 & 4,1 & 12 & 0,2 \\
\hline KHK (25) & 212 & 16,3 & 4,1 & 23 & 0,4 \\
\hline WSG (10) & 76 & 5,8 & 1,5 & 3 & 0,1 \\
\hline $\begin{array}{c}\text { Keseluruhan } \\
\text { (225) }\end{array}$ & 2106 & 18,0 & 40,5 & 164 & 3,2 \\
\hline
\end{tabular}

Tabel 1. Data Kelompok AUM Umum Kelas VII

\section{Masalah pada siswa kelas VIII}

Hasil dari pengisian AUM umum oleh siswa kelas VIII akan diuraikan dalam data kelompok, yang terdiri dari dua kelas (A dan B). Pada data kelompok kelas VIII bidang masalah pada PDP dan HSO. Berikut tabel data kelompok kelas VIII:

ANALISIS DATA KELOMPOK AUM UMUM KELAS VIII

\begin{tabular}{|c|c|c|c|c|c|}
\hline \multirow{2}{*}{$\begin{array}{c}\text { Bidang } \\
\text { Masalah }\end{array}$} & \multicolumn{2}{|c|}{ Masalah Keseluruhan } & \multicolumn{2}{c|}{ Masalah Berat } \\
\cline { 2 - 6 } & Jumlah & $\%$ & $\begin{array}{c}\text { Rata-rata } \\
\text { persiswa }\end{array}$ & Jumlah & $\begin{array}{c}\text { Rata-rata } \\
\text { persiswa }\end{array}$ \\
\hline JDK (25) & 175 & 17,9 & 4,5 & 21 & 0,5 \\
\hline DPI (20) & 171 & 17,5 & 4,4 & 12 & 0,3 \\
\hline HSO (15) & 283 & 29,0 & 7,3 & 32 & 0,8 \\
\hline EDK (15) & 49 & 5,0 & 1,3 & 3 & 0,1 \\
\hline KDP (15) & 75 & 7,7 & 1,9 & 6 & 0,2 \\
\hline PDP (55) & 501 & 51,4 & 12,8 & 72 & 1,8 \\
\hline ANM (15) & 213 & 21,8 & 5,5 & 31 & 0,8 \\
\hline KHK (25) & 138 & 14,2 & 3,5 & 17 & 0,4 \\
\hline WSG (10) & 61 & 6,3 & 1,6 & 7 & 0,2 \\
\hline $\begin{array}{c}\text { Keseluruhan } \\
\text { (225) }\end{array}$ & 1666 & 19,0 & 42,7 & 201 & 5,2 \\
\hline
\end{tabular}

Tabel 2. Data Kelompok AUM Umum Kelas VIII

\section{PEMBAHASAN}

Gambaran kondisi psikologis peserta didik dan implikasinya pada program bimbingan dan konseling

Siswa SMP merupakan remaja dengan rentang usia 12-14 tahun dengan tugas dan tahap perkembangan remaja awal (Sihotang \& Yusuf, 2013) antara lain: 1) mencapai pola hubungan baru yang lebih matang dengan teman sebaya yang berbeda jenis kelamin sesuai dengan keyakinan dan etika moral yang berlaku di masyarakat, 2) mencapai peranan sosial sesuai dengan jenis kelamin, selaras dengan tuntutan sosial dan kultural masyarakat, 3) menerima kesatuan organorgan tubuh/ keadaan fisiknya sebagai pria/wanita dan menggunakannya secara efektif sesuai dengan kodrat masingmasing, 4) menerima dan mencapai tingkah laku sosial tertentu yang bertanggung jawab di tengah-tengah masyarakat, 5) mencapai kebebasan emosional dari orang tua dan orang-orang dewasa lainnya dan mulai menjadi "diri sendiri", 6) mempersiapkan diri untuk mencapai karir (jabatan dan profesi) 
tertentu dalam bidang kehidupan ekonomi.

Tugas perkembangan tersebut menggambarkan pola perkembangan remaja yang meliputi belajar, sosial, karir, jasmani dan kesehatan. Dalam bidang belajar, remaja di sekolah melalui proses pembelajaran yang menuntutnya untuk terus memahami materi pelajaran dengan berbagai macam penyelesaian tugas, sehingga belajar menjadi suatu hal yang tidak menyenangkan bagi siswa (Barseli \& Ifdil, 2017). Untuk itu usaha konselor sekolah dapat melaksanakan layanan seperti layanan pengusaaan konten untuk meningkatkan kemampuan belajar siswa dengan berbagai model pembelajaran (Numri, 2015; Sartono, 2014), layanan informasi dengan metode blended learning dan media film juga dapat membantu untuk meningkatkan motivasi belajar siswa (Anggraeni, 2010; Desyafmi, Firman, \& Ifdil, 2016; Fitri, Ifdil, \& Neviyarni, 2016), serta layanan lainnya yang dapat mendukung kegiatan belajar siswa.

Segala kegiatan belajar siswa juga tidak terlepas dari hubungan sosialnya, ketika mereka berinteraksi di sekolah proses penerimaan teman sebaya sangatlah penting (Lutfi, 2012) sehingga, melalui penerimaan siswa dapat mengaktualisasikan diri lebih baik lagi, selain itu mendapatkan pengalaman sosial yang menjadi modal untuk mereka nanti. Tidak dipungkiri hubungan sosial juga dapat mempengaruhi proses belajar siswa, untuk itu penting bagi konselor sekolah dalam memperhatikan bagaimana pola hubungan sosial siswa serta bagaimana cara untuk mengembangkan hubungan sosial siswa di sekolah. Beberapa cara membantu siswa dalam mengembangkan hubungan sosialnya dapat melalui layanan informasi dengan berbagai media audiovisual (Febrita, Hartuti, \& Sinthia, 2014), layanan bimbingan kelompok dengan topik tugas untuk meningkatkan sopan santun dalam hubungan sosial (Roshita, 2015), layanan konseling kelompok yang membantu mengentaskan permaslahan hubungan sosial siswa (Stevani, 2018) dan layanan lainya di dalam bimbingan dan konseling. Selanjutnya jasmani dan kesehatan remaja yang menjadi permasalahan pada masa perkembangannya juga sangat perlu diperhatikan untuk itu dalam bimbingan dan konseling menyediakan pusat informasi dan kesehatan remaja (PIK-R) yang memberikan siswa pemahaman seperti kondisi perubahan fisik yang terjadi pada usia remaja dan bagaimana menghadapi hal tersebut.

\section{SIMPULAN}

Berdasarkan data yang diperoleh terkait gambaran psikologis peserta didik SMP IT Thariq bin Ziyad, Pada bidang masalah PDP dan HSO yang paling banyak mendapat perhatian. Adapun upaya yang dapat dilakukan dengan memberikan layanan seperti layanan informasi, konseling individu, bimbingan kelompok, konseling kelompok, mediasi, pengusaan konten dan konsultasi. Untuk itu hasil dari penelitian ini dapat menjadi bahan masukan bagi konselor sekolah dalam pembuatan program dan pelaksanaan layanan bimbingan dan konseling.

\section{DAFTAR PUSTAKA}

Afandi, R. (2011). Integrasi Pendidikan Karakter Dalam Pembelajaran Ips Di Sekolah Dasar (Vol. 1). Retrieved from http://pendikar.dikti.go.id/gdp/wpcontent/uploads/Desain-IndukPendidikan-Karakter- 
Anggraeni, A. (2010). Penggunaan media film untuk meningkatkan motivasi siswa mengikuti layanan informasi belajar dalam pelayanan bimbingan dan konseling di kelas viii smp $n 1$ semarang. Universitas Negeri Semarang.

Arikunto, S. (2006). Metodelogi penelitian. Yogyakarta: Bina Aksara.

Barseli, M., \& Ifdil, I. (2017). Konsep Stres Akademik Siswa. Jurnal Konseling Dan Pendidikan, $5(3)$, 143. https://doi.org/10.29210/119800

Desyafmi, H., Firman, F., \& Ifdil, I. (2016). Peningkatan Motivasi Siswa dalam Menyelesaikan Tugas Melalui Layanan Informasi. Konselor, 3(1), 3541.

Emosi, M., Jiwa, P., Rsupn, R., Wiguna, T., Samuel, P., Manengkei, K., ... Hapsari, W. A. (2010). Masalah Emosi dan Perilaku pada Anak dan Remaja di Poliklinik Jiwa Anak dan Remaja RSUPN dr. Ciptomangunkusumo (RSCM), Jakarta. 12(4), 270-277.

Febrita, D., Hartuti, P., \& Sinthia, R. (2014). Pengaruh Layanan Bimbingan Klasikal Menggunakan Media Audio-Visual Terhadap Hubungan Sosial Teman Sebaya Siswa Di Kelas VII Di SMPN 4 Kota Bengkulu. Universitas Bengkulu.

Fitri, E., Ifdil, I., \& Neviyarni, S. (2016). Efektivitas layanan informasi dengan menggunakan metode blended learning untuk meningkatkan motivasi belajar. Jurnal Psikologi Pendidikan Dan Konseling: Jurnal Kajian Psikologi Pendidikan Dan Bimbingan Konseling, 2(2), 84-92.

Iceu, R. (2011). Program bimbingan teman sebaya untuk meningkatkan percaya diri siswa. Jurnal Penelitian Pendidikan, Edisi Khus(2), 154-163.
Ifdil, I., \& Ilyas, A. (2017). Pengolahan Alat Ungkap Masalah (AUM) dengan Menggunakan Komputer Bagi Konselor. Jurnal Aplikasi IPTEK Indonesia, 1(1), 17-24. https://doi.org/10.24036/4.113

Imran, Y. (2013). Permasalahan Anak Asuh dan Aplikasi Pelayanan Konseling Terhadap Mereka. Jurnal Konseling Dan Pendidikan, 1(1), 6. https://doi.org/10.29210/1200

Lutfi, D. N. (2012). Hubungan Antara Dukungan Teman Sebaya Dengan Kemampuan Pemecahan Masalah Pada Santriwati Pengurus Organisasi Pelajar Ppmi Assalaam (OP3MIA). Universitas Muhammadiyah Surakarta.

Numri, M. (2015). Meningkatkan Kemandirian Belajar Melalui Layanan Penguasaan Konten Dengan Teknik Latihan Saya Bertanggungjawab. Jurnal Penelitian Tindakan Bimbingan $\mathcal{E}$ Konseling, 1(1), 48-53.

Nurhasanah, N., \& Farozin, M. (2019). The Identification of Students' Problems in Junior High School Using AUM Umum (General Problem-Revealing Instrument). 326(Iccie 2018), 377-381. https://doi.org/10.2991/iccie-18.2019.64

Puslitbang, P., Sosial, K., \& Timur, J. (2015). The Phenomenon of Juvenile Delinquency and Criminality. (200), 121-140.

Roshita, I. (2015). Upaya Meningkatkan Perilaku Sopan Santun melalui Layanan Bimbingan Kelompok dengan Teknik Sosiodrama. Jurnal Penelitian Tindakan Bimbingan $\mathcal{E}$ Konseling, 1(2).

Sartono, Y. (2014). Peningkatkan tanggungjawab belajar melalui 
Analisis Kondisi Psikologis... - Hayu Stevani, Riska Andriani, \& Fijriani Fijriani.

layanan penguasaan konten dengan teknik role playing. Jurnal Penelitian Tindakan Kelas, 15(4).

Sihotang, N., \& Yusuf, A. M. (2013). Pengaruh Layanan Bimbingan Kelompok Terhadap Pencapaian Tugas Perkembangan Remaja Awal dalam Aspek Kemandirian Emosional ( Studi Eksperimen di SMP Frater Padang ). 2(4).

Stevani, H. (2018). Layanan Konseling Kelompok Untuk Mengembangkan Hubungan Sosial Peserta Didik. WAHANA DIDAKTIKA, 16(3). 